\title{
Dürtme Bireysel Tasarrufları Etkileyebilir
} mi? ${ }^{1}$

\author{
Meltem ERdoĞAN (i] ${ }^{2}$ Veysel KARAGÖL (10 ${ }^{3}$
}

Başvuru: 11.09.2020; Düzenlenme: 29.09.2020; Kabul: 07.12.2020

\begin{abstract}
Kararlarında sinırsız rasyonaliteye sahip olduğu düşünülen bireyleri hedef alarak oluşturulan politikalar günümüzde ve geçmişte ortaya çıkmıs sorunların çözümünde yetersiz kalmaktadır. Hâlbuki davranış etkileyebilmek kamu politikası için oldukça önemlidir ve insanların davranışlarının hükümetin ihtiyaçlar üzerindeki etkisinin anlaşlması ile son zamanlarda politika tercihleri bu etkilerin bilinciyle yapılmaktadır. Bireylerin akıldışı davranışlar sergilemeleri davranı̧sal iktisadın her gün biraz daha yol kat etmesine sebep olmaktadır. Davranıssal iktisadın uygulamalarından biri olan dürtme ise basit ve düşük maliyetli yollarla akıldışı davranışların önlenmesini ve böylece bireylerin iyi ve doğruya yönlendirilmelerini amaçlamaktadır. Öyle ki, dürtme birçok alanda alternatif bir kamu politikası aracı olma yolunda hızla ilerlemektedir. Dürtme ile geleneksel politika yapım süreçleri yerine kanıta dayalı, test edilmiş politikalar tasarlayarak uygulamaya koymak politikaların başarı şansını da artırmaktadır. Bu açıdan bakıldığında, bireylerin finansal kararlarına yön vererek (dürterek) bireysel tasarrufların artırılmasın sağlamak bu alanlardan sadece birisidir. Peki, dürtme ile bireysel tasarrufları artırmak gerçekten mümkün müdür? Bu çalı̧̧manın amacı, dürtme mekanizmasının nasıl işlediğini ele alarak ve finansal kararların dürtülmesini içeren ampirik bulguları göz önünde bulundurarak, dürtme ile bireysel tasarrufların artırılıp artırılamayacağına ilişkin öneriler sunmaktır.
\end{abstract}

JEL kodları: D90, G51, J18

Anahtar kelimeler: Davranışsal İktisat, Dürtme, Kamu Politikası, Bireysel Tasarruflar

\section{Giriş}

Tasarruflar hem mikro hem de makro anlamda, gerek birey gerek kamu kesimi ve özel kesim açısından büyük öneme sahiptir. Be-

\footnotetext{
1 Bu çalışma, II. International Conference on Economics - EconTR adlı kongrede sözlü bildiri olarak sunulmuştur.

2 İktisadi ve İdari Bilimler Fakültesi, Anadolu Üniversitesi, Eskişehir, Türkiye. (e-mail: melteme@anadolu.edu.tr)

3 İktisadi ve İdari Bilimler Fakültesi, Anadolu Üniversitesi, Eskişehir, Türkiye. (e-mail: vkaragol@anadolu.edu.tr)
}

lirsiz geleceğini garanti altına almak bireyler için oldukça önemli bir gereklilik olup, özellikle emeklilik döneminde iyi koşullarda yaşama isteği doğrultusunda bireylerin tasarrufta bulunmaları elzemdir. Kamu tasarruflarmın yanında özel kesimi oluşturan bireylerin tasarrufları, hem uzun dönemde bireylerin refah düzeylerini etkileme hem de dolaylı olarak da olsa ülkelerin makroekonomik hedeflerine ulaşmalarını kolaylaştırabilme yetilerine sahiptir. Ancak bireysel tasarruflar gelir, eğitim, faiz oranı gibi birçok değişkenden etkilenmekte ve özellikle gelişmekte olan eko- 
nomiler çoğu zaman tasarruf yetersizliği sorunu yaşamaktadırlar. Ayrıca, Neo-Klasik iktisadın aksine son zamanlarda davranışsal iktisadın ele aldığ bilisssel yanlılıklar (cognitive biases), çoğunlukla bireylerin rasyonaliteden uzak kararlar vermelerine sebep olmakta ve tasarruf kararlarını önemli ölçüde etkilemektedir. Örneğin, bireylerin finansal açıdan okuma yazma bilmemeleri (Lusardi ve Mitchell, 2007; Bucher-Koenen ve Lusardi, 2011) ve özdenetim sorunları (Angeletos vd., 2001), bireylerin ihmalkârlıkları ve erteleme problemleri ile desteklenerek, emeklilikleri için özellikle bugün yeterince tasarrufta bulunmadıklarına dair kantlar sunmaktadır. $\mathrm{Bu}$ durum, politika yapıcıları ve kuruluşları daha yüksek tasarrufları teşvik eden politikalar uygulamaya yöneltmektedir. Bunlar arasında özellikle son yıllarda bireysel tasarrufların teşvik edilmesini ve artırılmasını amaçlayan farklı birçok dürtme uygulaması başarılı sonuçlara imza atmıştır. Bu uygulamaların temel amaçları, bireylere finansal planlama ve paranın kullanımı konularında farkındalık yaratarak öncelikle kendilerine rahat bir emeklilik dönemi sağlamaktır. Bu uygulamalar aynı zamanda devletler için potansiyel sosyal güvenlik sistemi sorunlarını önüne geçebilmek adına gerekli bir adım olarak görülmektedir. Bu çalı̧̧mada, dürtme uygulamalarının bireysel tasarrufları etkilemedeki rollerinin ve bu tür uygulamaların etkinliğini artırabilmek adına birtakım önerilerin gündeme getirilmesi amaçlanmıştır. $\mathrm{Bu}$ bağlamda, öncelikle bireysel tasarruflara ilişkin teorik yaklaşımlar ele alınmış ve bireysel ve toplam tasarruflarm önemi kısaca açıklanmıştır. Ardından, tasarrufları artırmaya yönelik ampirik dürtme uygulamalarına yer verilmiştir. Bu kapsamda bireyleri herhangi bir tasarruf planına dâhil etmenin ilk yolu olarak ön tanıml seçenek (default option) kuralının değiştirilmesi, bireylere işe başlarken olabildiğince sadeleştirilmiş kayıt formlarıyla bu plana katılmak isteyip istemediklerinin sorulması, bireylerin tasarruf katkı oranlarını kendilerinin belirleyebilmelerine olanak tanınması gibi farklı yöntemler detaylı biçimde ele alınmıştır. Bunların yanında, farklı ülkelerle birlikte Türkiye'de de uygulanan ve tasarruflarm artırılmasında başarılı sonuçlar elde edilmesine yol açan Otomatik Katılım Sistemi (OKS) ile R. H. Thaler ve Benartzi (2004) tarafindan ortaya atılan Yarın Daha Fazla Tasarruf Edin (Save More Tomorrow-SMarT) Programı detaylı bir şeklide açıklanmıştır. Yine, birtakım hatırlatıcıların ve tasarruf araçlarının özellikle düşük gelirli bireylerin tasarruf etmelerindeki rollerini vurgulayan bazı çalışmalara etraflıca değinilmiştir. Çalışmanın son bölümünde ise $\mathrm{R}$. Thaler ve Sunstein (2008)'in çalışmalarında da belirttikleri üzere, finansal eğitimin, bireylerin tasarruf kararları verirken daha iyi seçim yapabilmeleri adına belirleyici bir faktör olmasına rağmen tek başına bir çözüm olmamasından yola çıkılarak, bireylerin özellikle tasarruf konusundaki irrasyonel davranışlarının sebepleri Dawnay ve Shah (2005) çalışması temelinde açılklanmıştır. Böylece bireyleri tasarrufa yönlendirebilmek adına etkili dürtme tasarımının nasıl olması gerektiğine ve tasarruf etmeyi sağlayan ampirik kurallara yer verilmiş, nihayetinde bireylere ve politika yapıcılara yönelik bazı önerilerde bulunulmaya çalışılmıştır.

\section{Bireysel Tasarruflara Yönelik Teorik Yaklaşımlar}

Poterba (2002), bireysel tasarrufları iki farklı açıdan tanımlamıştır. Bunlardan ilki, belirli bir zaman dilimindeki bireysel harcanabilir gelirden bireysel harcamalarm çıkarılmasıdır. İkinci tanımda ise ilk tanıma, yine aynı dönemdeki mevcut varlıklar üzerinden bireylerin elde ettikleri herhangi bir sermaye kaybı veya kazancı eklenmekte ve böylece bireysel tasarruflar, belirli bir zaman dilimindeki net servet değişiklikleri olarak tanımlanmaktadır. Ancak sermaye kayıp ve kazançlarını ölçmek sorunlu bir iş olduğundan bireysel tasarruflar ile ilgili çalışmaların çoğu (genellikle emeklilik fonu rezervlerini de içerecek şekilde bir değişiklikle) ilk tanıma dayanmaktadır. 
Katona (1975) ise ortalama bir bireyin kendini gelecekteki belirsizlikten korumak veya yine gelecekte mal ve hizmet satm alabilmek için paralarını banka hesaplarında tutarak ya da başka türlü varlıklarla tasarruf ettiklerini söyleyerek, tasarruflarm daha mikro temelli tanımını ortaya koymuştur (Katona, 1975; Lunt ve Livingstone, 1991). Bireysel tasarrufların gelir ve servet dışında farklı dinamikleri de bulunmaktadır. Ĕ̆itim, statü, ırk, yaş ve çevresel etmenler gibi demografik faktörlerin yanında belirsizlik, faiz oranı, maliye politikası ve finansal piyasalara erişim gibi birçok etmen bireysel tasarruf kararlarını etkilemektedir (Rocher ve Stierle, 2015). Beverly (1997), bireysel tasarruflara ilişkin teorik yaklaşımları temelde dört kategoride incelemektedir:

- Neo-Klasik İktisat teorileri: Burada Neo-Klasik iktisadın temel varsayımlarından olan rasyonel birey ve fayda maksimizasyonu geçerlidir. Tüketimlerinin finansmanını ellerindeki geliri ve diğer varlıkları kullanarak sağlayacak olan bireyler, fayda maksimizasyonu amacına uygun olarak şimdiki ve gelecekteki tüketimi arasında bir seçim yaparlar. Tasarruflar, geleceğe fayda sağlayacak uzun vadeli tüketim için bir gelir olarak görülmektedir.

Yaşam Boyu Gelir Hipotezi (Modigliani ve Brumberg, 1954) ile Sürekli Gelir Hipotezi (Friedman, 1957) bireylerin tüketim ve tasarruf kararlarını analiz etmek için kullanılan standart Neo-Klasik modellerdir. Yaşam Boyu Gelir Hipotezi'nde bireyler, tüketim ve tasarruf kararlarmı uzun dönemli olarak planlarlar. Geliri artarken tasarrufa yönelen birey, gelirinin azaldığı emeklilik dönemlerinde ise artan tasarrufları ile tüketim harcamalarını devam ettirir. Sürekli Gelir Hipotezi'nde ise birey, tüketim ve tasarruf kararlarını gelirindeki geçici artış ve azalışları değil, yaşam boyu elde etmeyi umduğu sürekli gelirini dikkate alarak verir.

- Psikolojik ve sosyolojik teoriler: $\mathrm{Bu}$ teoriler, tüketicilerin zevk ve isteklerinin sabit olmadı $\breve{g}_{1}$, bunun yerine ekonomik veya sosyal uyarıcı ve koşullardan etkilendikleri varsayımına dayanmaktadır. Öyle ki, bireylerin niyetlerini ve beklentileri önemli ölçüde etkileyen bu dış uyarıcılar tasarruf kararlarının anahtarı konumundadırlar. Finansal okuryazarlık ve tasarruf güdüsü gibi psikolojik faktörler ile sosyalleşme, grup normları ve çevresel özellikler gibi sosyolojik faktörler bu teorilerin önemli değişkenleri arasında sayılabilir.

- Davranış teorileri: Davranış teorilerine göre tasarruf tercihleri sabit olamamakla birlikte ekonomik kaynaklarla da belirlenmemektedir. Bunun yerine bireyler, diş uyaranlarla birlikte kendi davranışsal teşviklerini ve kısitlamalarını yaratmaktadır. $\mathrm{Bu}$ teorilerin en başında Shefrin ve Thaler (1977)'in İradenin Ekonomi Teorisi (Economic Theory of Self-control) gelmektedir. Bu teoride Shefrin ve Thaler iki farklı karar vericiden bahsederler: Planlayan ve yapan. Planlayan, ömür boyu faydasını göz önüne alırken, yapan yalnızca içinde bulunduğu dönem ile ilgilenir. $\mathrm{Bu}$ nedenle, geleceği düşünmeden hareket eden bireylerin irade göstermesi için tercihlerinin değiştirilmesine yönelik olarak bir dizi teşvike ve kısıtlayıcıya gerek duyulabilmektedir. 
- Kurumsal teoriler: $\mathrm{Bu}$ teoriler bireysel tasarrufların, tasarrufun gerçekleştiği kurumsal süreçler tarafindan şekillendikleri fikrine dayanmaktadır. Tasarruflara ilişkin kurallar, teşvikler ve sübvansiyonlar bu kurumsallaşmış mekanizmanın bir sonucu olup kurumlara erişimi olan bireylerin varlık biriktirmesi rasyoneldir.

\section{Bireysel Tasarrufların Önemi}

Bireysel tasarruflarm öncelikli hedefi bireylerin kendi refahlarıdır. Ancak bireylerin kendi gelecekleri için yaptıkları tasarrufların büyüklüğünün, potansiyel makroekonomik etkileri de göz ardı edilemeyecek öneme sahiptir. Tasarruflarm makro anlamdaki önemi sürdürülebilir ekonomik büyüme ve kalkınmanın sağlanması ile bağlantılı olarak ortaya çıkmaktadır. Bunlar, özellikle gelişmekte olan ülkelerin temel hedefleridir. Ülkeler bu hedeflerine ulaşmak için birçok politika stratejisi geliştirmektedir. Ancak ülkeler arasındaki büyüme ve kalkınma düzeyleri buna rağmen birbirinden çok farklıdır. Çünkü bu hedeflerin sağlanması temelde ülkelerin yatırım, sermaye oluşumu ve üretim kapasiteleriyle bağlantılıdır. Bu yatırım ve sermaye oluşumu ile nihayetinde üretimin gerçekleşmesi için kaynak tedariki, büyük ölçüde ülkenin tasarruflarına bağlıdır (Niwanthika, 2016).

Gelişmekte olan birçok ülke gibi Türkiye'nin de önemli ekonomik sorunlarından biri tasarrufların yetersizliğidir. Öyle ki, Türkiye'nin toplam tasarrufları, kriz dönemleri dışında, sabit sermaye yatırımlarını karşılamakta yetersiz kalmakta ve tasarruf-yatırım açı̆̆ı meydana gelmektedir. Türkiye, bu tasarruf oranları ile 2018 verilerine göre Çin (\%44), Güney Kore $(\% 35,7)$, Hollanda $(\% 31,9)$, Endonezya $(\% 31,8)$, Hindistan $(\% 31,1)$, Rusya $(\% 29,9)$, İsveç $(\% 28,4)$ ve Japonya $(27,8)$ gibi ülkelerin gerisinde kalmıştır (World Bank). Ayrıca TÜIKK hanehalkı anketlerine göre bireylerin kullanılabilir gelirinden tüketim harcamalarının çıkarılması şeklindeki ba- sit tasarruf tanımı itibari ile 2003 yılında \%17,5 olan bireysel tasarruf oranı, 2013 yılına gelindiğinde $\% 7,5$ 'lere kadar düşüş göstermiştir (Pektaş Erdem, 2017). Tasarruflardaki bu düşük oran oldukça dikkat çekicidir. İç tasarruflarm yetersiz kalması, ekonomik büyüme ve kalkınma hedefleri doğrultusunda dış kaynaklara bağımlılığı beraberinde getirmektedir. Ancak birçok kez tecrübe edilmiştir ki dış kaynaklarla söz konusu hedeflere ulaşabilmek dönemliktir. Yani herhangi bir süreklilik ve sürdürülebilirlik özelliği taşımamaktadır. Bu makro etkilerin yanında, esasında bu çalışmanın ilgilendiği temel alan daha önce de belirtildiği üzere bireylerin refah düzeyidir. Özellikle bir takım davranışsal ve psikolojik sebeplerle bireyler uzun dönemli tasarruflardan kaçınmakta ve bu durum bireysel refahın azalmasina sebep olmaktadır. Can ve Erdem (2013) ve Zengin ve Yüksel (2018) Türkiye'de bireylerin tasarruf kararlarını etkileyebilmek ve bireysel refahı artırabilmek için politika müdahalelerine gerek duyulduğunu vurgulamışlardır. Buna göre, politika yapıcılar sürdürülebilir bir finansal yatırmm ve toplam tasarruf seviyesi sağlanarak yetersiz tasarruf sorununun çözülebilmesi adına bireylere yönelik yol gösterici müdahalelere başvurabilirler.

\section{Tasarrufları Artırmaya Yönelik Am- pirik Dürtme Uygulamaları}

Bireylerin bilişsel yanlılıkları, çoğu zaman onların rasyonaliteden uzak bir biçimde kararlar vermelerine sebep olmakta ve tasarruf kararlarını önemli ölçüde etkilemektedir. Ancak tasarruflar, bireylerin öngöremedikleri gelecekteki refah düzeyleri açısından önemli etkiler barındırmaktadır. Bu nedenle, özellikle son yıllarda bireysel tasarruflarm teşvik edilmesini ve artırılmasını amaçlayan farklı birçok dürtme uygulaması ortaya çıkmıştır. Bu uygulamaların temel amaçları, bireylere finansal planlama ve paranın kullanımı konularında farkındalık yaratarak öncelikle onlara rahat bir emeklilik dönemi sağlamaktır. Bu uygulamalar aynı zamanda devletler için potansiyel sosyal güvenlik 
sistemi sorunlarının önüne geçebilmek adına gerekli bir adım olarak görülmektedir. Bu tür emeklilik planı uygulamalarına katılmanın yolu, öncelikle onlara kaydolmaktır. Bazı bireyler bu tür uygulamaları yararlı bulsalar da, diğer birçoğu sahip oldukları bilişsel yanlılıklar nedeniyle bunu reddedebilmektedirler. $\mathrm{Bu}$ durum, çoğunlukla bireylerin tasarruf etmek istememelerinden değil, onların ihmalkârlıklarından ve ertelemelerinden kaynaklanmaktadır. Dürtme uygulamalarının örneklem grubu tam olarak bu bireylerden oluşmaktadır. Bu bireyleri herhangi bir tasarruf planına dâhil etmenin ilk yolu ön tanımlı seçenek kuralını değiştirmektir. Yani herhangi bir aktif seçim yapilmaması halinde maruz kalınan durum bu sisteme katılmama değil aksine, katılma olarak değiştirilmelidir. Böylece birey, bu plana otomatik olarak dâhil edilmekte ve bu plandan ayrılmak istediği durumda bireyden bir belge doldurması beklenmektedir. Buna yönelik olan OKS uygulaması, ABD'de maaş esaslı emeklilik planlarına katılımı önemli ölçüde artırmıştır. İkinci bir yol, bireyler işe başlarken olabildiğince sadeleştirilmiş kayıt formlarıyla, onlara bu plana katılmak isteyip istemediklerinin sorulmasıdır. Çünkü seçenek sayısı arttıkça bireylerde kafa karışıklığı meydana gelmekte ve bazı insanlar seçim yapmaktan vazgeçebilmektedir. Diğer bir yol, bireylerin katkı oranlarını kendilerinin belirleyebilmelerine olanak tanımaktır. Burada hükümet veya işveren, bireyin yapacağ 1 minimum tutardaki bir tasarruf için katkı payı sağlayabilmektedir. Eğitim ise bireylerin daha iyi seçim yapabilmeleri adına belirleyici bir diğer faktördür. Özellikle finansal okuryazarlık oranı yüksek olan bireylerin tasarruf oranlarmm da yüksek olduğu bilinmektedir. Ancak yine de eğitim tek başına bir çözüm değildir (R. Thaler ve Sunstein, 2008).

Bunlardan OKS'yi uygulayan ülkelerden biri de Türkiye'dir. 1 Ocak 2017 tarihinde var olan bireysel emeklilik kanunu değiştirilmiş ve hükümetin ve işverenlerin 45 yaş altı çalışanlarını prime esas kazançlarının

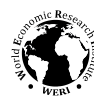

\%3'ü ile otomatik bir emeklilik planına dâhil edilmesi şeklinde düzenlenmiştir. Böylece çalışanlar bireysel emeklilik sistemine otomatik olarak dâhil edilmiş, ancak sisteme dâhil olduktan sonraki iki ay içerisinde herhangi bir kayba uğramadan cayma hakları ise saklı tutulmustur. Bunun yanında önceden vaat edilen \%25'lik devlet katkısına, en az on yıllık gelir sigortası yapmak kaydıyla ekstra $\% 5$ devlet katkısı ve sistemde kalınması halinde doğrudan 1000 TL'lik devlet katkısı ilave edilmiştir (Emeklilik Gözetim Merkezi, 2020). Emeklilik Gözetim Merkezi'nin verilerine göre OKS'ye hali hazırda devam eden çalışanların sayısı 7 milyona yaklaşmaktadır. Ayrıca OKS'den önce BES'e girmiş olanların OKS'ye devam oranı \%34,9, OKS'den önce BES'e girmemiş olanların OKS'ye devam oranı ise \%48'dir.

R. H. Thaler ve Benartzi (2004) daha fazla tasarruf etmek isteyen ancak bu isteğe göre hareket etme iradesine sahip olmayan çalışanlara yardımcı olmak adına Yarın Daha Fazla Tasarruf Edin Programı'nı tasarlamıslardır. $\mathrm{Bu}$ program bireylerin davranışlarındaki beş psikolojik faktör ile yakından ilişkilidir (R. Thaler ve Sunstein, 2008):

- Birçok birey daha fazla tasarruf etmeyi düşünür ve planlar, ancak bu planları asla hayata geçirmez.

- Gelecekte meydana gelecek irade kısıtlamalarını benimsemek, söz konusu kısitlamaları bugün gerçekleştirmekten daha kolaydır. Örneğin, bireyler yakın zamanda diyete başlayacaklarını söylerler ancak asla bugün demezler (hyperbolic discounting).

- Bireyler maaşlarmda bir düşüş görmek istemez, kayıptan kaçınırlar (loss aversion).

- Parasal kayıplar, nominal olarak hissedilir (money illusion). 
- Atalet güçlü bir rol oynar (inertia).

Yarın Daha Fazla Tasarruf Edin Programı'nda bireylerin maaşları arttıkça tasarruf oranları da aynı oranda artmaktadır. İlk kez 1998'de orta ölçekli bir şirkette uygulanan program, çalışanlara dizüstü bilgisayar eşliğinde bir finans danışmanıyla yüz yüze görüşme olanağı tanımıştır. Çalışanların \%90'ı finans danışmanını kabul etmiş ve finans danışmanı çalışanlardan aldığ ladığı kadarıyla çoğu çalışana maaşlarının yaklaşık \%15'ini tasarruf etmeleri gerektiğini ögütlemiştir. Ancak bu hedef tüm çalışanlar tarafindan anında reddedilince yeni hedefi yaklaşık \%5 olarak belirtmiştir. Bu sefer de çalışanların yalnızca $\% 25 \%$ bu teklifi kabul etmiş, diğerleri ise bu oranda bir gelir azalmasını yine fazla bulmuşlardır. $\mathrm{Bu}$ aşamada devreye sokulan program, tasarrufların maaş artış oranlarıyla aynı düzeyde olacağı (yaklaşık \%3) ve maaş artışı oranında tasarruf oranının da güncelleneceği yönünde bir teklif ile gelmiştir. Bu teklifi ise çalışanların $\% 78$ 'i onaylamıştır. Maaş ile tasarruf oranlarındaki artış uyumlu olunca bireyler ellerine geçecek parada eksilme yaşamayacağı gözüyle bakarak, artan emeklilik kesintilerini kayıp olarak görmemişlerdir. Sonraki yıllarda birçok emeklilik planı yöneticisi bu programı benimsemiş ve OKS ile birlikte kullanıldığında daha etkili sonuçlar verdiği tespit edilmiştir (R. H. Thaler ve Benartzi, 2004; R. Thaler ve Sunstein, 2008).

Emeklilik tasarruflarına ilişkin üç aşamalı bir çalı̧̧mada Messacar (2016), çalışmanın ilk aşamasında bireylerin tasarruf etmelerinin önündeki engellerin kaldırılmasına yardımcı olacak uygun bir mekanizma olup olmadığını araştırmıştır. Kanada için yapılan bu çalışmada tasarrufların desteklenmesine yönelik olarak verilen işveren katkı paylarındaki her 1 dolarlık artışın yaklaşık 50 sentlik bir tasarruf sağladığı tespit edilmiştir. Bu şekilde bir dürtmenin özellikle düşük eğitimli çalışanlar için daha etkili sonuçlar verdiği belirtilen çalışmanın ikinci aşamasında ise tasarruf konusunda hâlihazırda yetersiz bilgiye sahip olan bireylerin emekliliğe nasıl hazırlanacakları hususunda bilgilendirilmeleri yoluyla dürtme uygulanmiştır. Burada, bireysel tasarrufları teşvik edecek sosyal açıdan etkili programların bir dürtme olarak uygulanması durumunda etkili sonuçlar alınabileceğinin altı çizilmiştir. Çalışmanın son aşamasında ise emeklilik tasarruf hesabındaki meblağının zamanından önce çekilmesinin önüne geçen stopaj vergisi kesintisi üzerinde durulmuştur. Stopaj vergisinin bir caydırma sağladı̆̆ 1 ve bireylerin yeterince para biriktirebilmek adına mücadele etmelerine neden olduğu belirtilmiştir. Bir diğer çalışmada ise Clark vd. (2017), Kuzey Carolina'da işveren tarafindan sağlanan tamamlayıcı tasarruf planlarının önemli yönleri hakkındaki bilgi amaçlı bir dürtme broşürünün çalışanlar üzerindeki etkisini araştırmıştır. Bu bilgilere erişimi sağlanan deney grubundaki bireylerin, herhangi bir bilgi verilmeyen kontrol grubundakilere göre emeklilik planına daha yüksek bir katılım sağladıkları belirlenmiştir. Bireysel tasarrufların artırılmasının teşviki yalnızca emeklilik planlamalarını içermemekte, esasında belirli bir gelir elde eden her yaştan insanı ilgilendirmektedir. Kolombiya'da düşük gelirli gençler arasında yapılan bir çalışmada Rodríguez ve Saavedra (2016), cep telefonları aracıllğ̆ıyla iletilen finansal durum bilgilendirme mesajlarmm finansal kararlar üzerindeki etkilerini incelemişlerdir. Bir yıl boyunca devam eden deneyde gençlere aylık ve 15 günlük tasarruf hatırlatıcı mesajlar ve aylık finans eğitimi mesajları iletilmiştir. Bir yılın sonunda aylık ve 15 günlük hatırlatma mesajları alan deney grubundaki gençlerin, kontrol grubundakilere kıyasla banka bakiyelerinde, sırasıyla $\% 28$ ve $\% 43$ oranında artış tespit edilmiştir. Bu artışların 3'te 2'sinden fazlasının net tasarruf olduğu belirlenmiştir. Ancak finans eğitimi amacıyla gönderilen mesajların anlamlı bir etkisi olmadığ ortaya konmuştur. 
Ashraf, Karlan, ve Yin (2006) ise dürtmenin düşük gelirli bireylerin tasarruflarını artırıp artırmayacağına dair bir araştırmayı Filipinler'de yapmışlardır. Bir Filipin Bankası'na tasarruf et, kazan, keyfini çıkar (Save, earn, enjoy deposit - SEED) adında bir tasarruf aracı kazandırmışlardır. Bu aracın en önemli özelliği, hesap istenen düzeye ulaşıncaya kadar bireylerin tasarruflarma erişimlerini kısıtlamasıdır. Yalnızca bu kısitlamayı taahhüt eden bireylere özel olan bu aracın amacı, bireylerin irade eksikliklerinin ve basiretsiz davranışlarının önüne geçmek olmuştur. Rastgele 710 müşteriye sunulan bu aracı müşterilerin 202'si (yaklaşık $\% 28,4$ 'ü) kabul etmiş ve hesap açmıştır. Bir yılın sonunda deney grubundakilerin ortalama tasarruf bakiyeleri, kontrol grubundakilere oranlara \%81 artmıştır. Bu hesabı açanların tasarruf oranları altı ayın sonunda $\% 192$, bir yl sonra ise \%337 oranında artış göstermiştir. Çalı̧̧ma, düşük gelirli bireylerin de tasarruf yapabileceklerine dair önemli kanıtlar sunmuştur.

Çalı̧̧manın bu bölümünde, bilişsel yanlılıkları göz önünde bulundurup bazı önkoşullara riayet ederek, düşük gelirli bireyler de dâhil olmak üzere, bireylerin tasarruf kararlarını etkilemede başarılı olan dürtme uygulamaları açıklanmıştır. Sonraki adımda ise bu başarılı uygulamaların etkili bir şekilde işlemesinin altında yatan mekanizmaya ve bazı önerilere yer verilmiştir.

\section{Tasarrufları Artırabilmek Adına Et- kili Dürtme Tasarımı ve Öneriler}

Bireysel tasarruf kararlarında iyi bir gelir elde etmek veya temel düzeyde ekonomi ve finans bilgisine sahip olmak her zaman yeterli olmamakta, dolayısıyla bireyler tasarruf kararları sürecinde yönlendirilme ihtiyacı duymaktadırlar. Son yıllarda çevre, sağlık, enerji tasarrufu, trafik kuralları, eğitim ve istihdam gibi birçok alanda yer edinen dürtme uygulamalarıyla, hem bu alanlarda hem de bireysel tasarrufların artırılması hususunda başarılı sonuçlar elde edilmiştir.
Ancak bu sonuçları elde edebilmek adına temelde iki olguyu mutlaka göz önünde bulundurmak gerekmektedir. Bunlardan ilki, tasarrufa yönlendirilmek istenen bireylerin bunu neden yapmaları gerektiği hususunda onları açıkça bilgilendirmektir. Peki, bireyler kendi çıkarları doğrultusunda niçin tasarruf etmelidir? Her birey için her zaman geçerli olmasa da genel anlamda bunun birden fazla nedeni bulunmaktadır. (i) Bireylerin ilerleyen yaşlarda gelirleri azalacak ve sağlık harcamaları artacaktır. (ii) Bireylerin çalışma oranları azaldıkça boş zaman oranları artacak ve bu zamanı kaliteli ve konforlu bir şekilde geçirmek isteyeceklerdir. (iii) $\mathrm{Bu}$ amaçla hem gezmek ve eğlenmek için hem de ev, araba gibi sabit sermaye yatırımları için nakde ihtiyaç duyacaklardır. (iv) Bunun yanında, çocuklu bireylerin yine ilerleyen yaşlarda çocuklarının hem birtakım sosyal ihtiyaçları hem de eğitim masrafları için harcamaları artacaktır. (v) Ayrıca hiç akla gelmeyen, beklenmedik ve nakit ihtiyacı gerektiren durumlarla karşlaşmaları da yine tüm bireyler için olasıdır. Dolayısıyla, tüm bireyleri bu konuda bilgilendirecek bir eğitim yapısının gerekliliği su götürmez bir gerçek olduğu gibi, yalnızca eğitim ve bilgilendirme ile farkındalık yaratılmasının tek başına yeterli olmadığı ampirik çalışmalarla da elde edilen önemli bir bulgudur. Tam da burada davranışsal iktisadın rolü devreye girmektedir. Davranışsal iktisat, bireylerin sınırlı rasyonaliteye sahip olduklarmı bilmekte ve bireylerin daha fazla tasarruf edebilmek için yönlendirilmeye (dürtülmeye) ihtiyaç duyduklarını öne sürmektedir. Davranışsal iktisat, bireylerin bu sınırlı rasyonelliklerinin nedenlerini ortaya koymakta ve bu nedenler esasında bireyleri dürtme konusunda önemli birer silah görevi görmektedir. Bireylerin bilişsel yanlılıkları olarak bilinen bu rasyonaliteden sapmalarını dikkate alan uygulamalar, tasarrufları artırmada başarılı sonuçlar elde edebilmeyi sağlayacak ikinci önemli husustur. Bireyleri tasarruf etmekten alıkoyan bilişsel yanlılıkların bilinmesi, spesifik bir şekilde bu yanlılıklara eğilen 
uygulamalar hazırlanmasına önayak olacak ve nihayetinde başarıyı da beraberinde getirecektir. Dawnay ve Shah (2005), standart iktisat teorilerinin aksine bireylerin rasyonaliteden sapmalarmmn nedenlerini yedi temel ilke ile açıklamaktadır. Bunlar:

1) Başkalarının davranışları bireyler için önemlidir. Bireylerin davranışları sabit değildir ve başkalarının yaptıklarından önemli ölçüde etkilenirler. Eğer komşusu veya bir yakını tasarruf ediyorsa bu durumun bireyi etkilemesi muhtemeldir.

2) Bireylerin alı̧̧kanlıkları vardır. Sik sık tekrar eden ve ucunda ödül olan alışkanlıklar güçlüdür ve kolay kolay değişmezler. Bunun için tasarrufu bilinçli bir şekilde düşünmeye teşvik eden tasarruf planları, bu planlara katılmayı kolaylaştıran (daha kısa bir form veya banka şubesine yürümek zorunda olmamak gibi) uygulamalar ve daha az ama daha sık tasarruf etmeyi teşvik eden ödüllendirici geri bildirimler vermek gibi uygulamalar etkili olabilmektedir.

3) Bireyler doğru olanı yapma konusunda motive olurlar. Bunun için bireylere sunulan şemanın doğruluğu ve inandırıcılığı bireyleri etkilemektedir.

4) Bireylerin beklentileri, davranışlarını etkiler. Burada yazılı, halka açık ve baskısız taahhütler, bireylerin davranışlarını etkileyebilmekte ve tasarruflarma uzun dönemde devam etmelerini sağlayabilmektedir.

5) Bireyler kayıptan kaçınırlar. Bu nedenle tasarruf konusunda verilmek istenen mesaj çerçevelenirken (fra- ming) 'bu plana katılmayarak 1000 TL kaybetmiş olursunuz' şeklinde ise 'bu plana katılarak $1000 \mathrm{TL}$ kazanabilirsiniz' şeklindeki bir mesajdan daha etkili olacaktır.

6) Bireyler hesaplama yapmakta kötüdürler. Bireylerin bazı bilişsel yanlılıkları onlarm iyi hesaplar yapabilmelerine engel olmaktadır.

- Bireyler gelecekteki olayları olduğundan daha az tahmin etmekte ve kisa vadeli tatminlere daha fazla önem vermektedir (hyperbolic discounting). Onlara yetersiz tasarrufun yol açabileceği sorunların açıklanması etkili olabilir. - Bireyler bilginin sunum şeklinden etkilenirler (framing effect). Tasarruf planının bireylere sunum şekli, kayıptan kaçınma durumunda olduğu gibi, onları etkileyebilmektedir. - Bireyler ön tanımlı seçeneklerden etkilenirler (default option). Her ay belirli bir meblağın ödenmesi için ödeme emri vermek veya OKS'deki gibi ön tanımlı olarak verilen otomatik katılma seçeneği yararlı olabilmektedir.

- Bireyler onlara sunulan başlangıç noktası çıpalarından etkilenirler (anchoring). Maksimum tasarruf oranının ne olabileceğinin belirlenmesi ve bir hedef olarak sunulması etkili olabilir. - Bireyler sezgileri ile karar verebilirler (heuristics).Sezgileri ile karar vermek bireyleri uzun uzun hesaplamalar yapmaktan alıkoyarak hızlı karar vermelerine neden olur. Bu nedenle onların düşünme süreçlerini olabildiğince kolaylaştırmak faydalı olabilir.

- Bireyler zihinsel muhasebe yapmakta zorlanabilirler (mental accounting).Bireyler para verilen bir etiketin kaynağına önem verir- 
ler. Yaz tatili hesabı, kırmızı spor araba hesabı gibi adlar verilen bir tasarruf hesabı tasarruf konusunda teşvik edici olabilmektedir.

7) Bireyler bir değişiklik yaparken kontrolün daima kendilerinde olduğunu hissetmelidirler. Bireylere ödeme sıklığ1 ve zaman dilimi hususlarında esneklik sağlayabilecek tasarruf planları sunulmalıdır.

Bireyleri tasarrufa yönlendirebilmek adına öncelikle onların bunu niçin yapmaları gerektiğine dair onları bilgilendirmek ve ardından ortaya konacak dürtme uygulamalarında bireylerin bilişsel yanlılıklarını dikkate almak iki temel gereklilik olarak karşımıza çıkmıştır. Bu ikisi bir araya getirildikten sonra geriye; iyiye ve doğruya yönlendiren, düşük maliyetli ve zorunluluk içermeyen (R. Thaler ve Sunstein, 2008), etkili dürtme uygulamaları tasarlamak kalmaktadır. Uzmanlara göre etkili bir dürtme tasarımı iki aşamadan oluşmaktadır (Financial Advice Working Group, 2020):

1) Tasarruf etmesi hedeflenen bireylerin harekete geçmemesinin altındaki nedenleri belirlemek: Burada bireylerin hangi bilişsel yanlılıklarmın tasarruf etmelerine engel olduğunun açıkça ortaya konması gerekmektedir. Örneğin, insanlar mevcut tüketimlerine gelecekteki tüketimlerinden daha fazla değer verdiklerinden, finansal sisteme güvensizlikten veya bunun basit bir is olamadığını düşündüklerinden birikim yapmiyor olabilirler.

2) Dürtmeyi, bireylerin eylemsizliklerinin nedenini ele alacak şekilde tasarlamak: Nasıl, kimi, ne zaman ve nerede dürtmeli gibi sorularm cevabı aranmalıdır.
- Nasıl? Dürtme duygusal bir tepkiyi tetiklemeli veya davranış ilkelerinden yararlanmalıdır.

- Kimi? Güvenilir ve alakalı bireylerde dürtmenin etkili olma olasılığ 1 daha yüksektir.

- Ne zaman? Tüketicinin finansal bir karar vermek üzere olduğu ve finansal rehberliğge ihtiyaç duyduğu an en sorunsuz andir.

- Nerede? Kamusal bir alana yerleştirilmiş bir broşür veya poster, bir internet sayfası veya doğrudan bir e-posta veya cep telefonu mesajı şeklinde günlük yaşamdaki iletişim kanallarından biri aracılı̆̆ııla paylaşılması gerekir.

Tablo 1'de, birtakım ampirik bulgular sonucunda elde edilmiş, tasarruf etmeye yardımcı olabilecek ampirik kurallar sıralanmıştır. Buna göre, bireylerin finansal durumlarinı sık sık kontrol etmeleri, borçlarının gerçek maliyetlerini bilmeleri, az da olsa gelirlerinin bir kısmını tasarruf için ayırabilmeleri, emeklilik tasarruflarını artırmaları ve bunları yaparken finansal destek almaları bireylerin tasarruflarını artıracak eylemler arasında sayılmaktadır. Ancak bireyleri tasarrufa yönlendirme hususunda en önemli görev, hatırlatıcılar kullanmak ve yeni ürünler geliştirmek suretiyle finansal kurumlara, işverenlere ve kamu otoritelerine düşmektedir.

Tüm bu bilgiler göz önüne alındığında dürtme uygulamalarının etkili bir şekilde işlemesinin kolay bir iş olmadı $\breve{g}_{1}$, ancak bazı ipucu ve kurallarm bu hususta işe yarayabildiği görülmektedir. (i) Bireyler, çoğunlukla uzun vadeli faydayı göz ardı edip kısa vadeli düşünerek bugün yanlı (present bias) davranmaya meyillidir. Tasarruf etmeyi düşünse dahi bunu hayata geçirmesi pek kolay olmayacaktır. Ampirik bulgular, Shefrin ve Thaler (1977)'in ortaya koydukları İradenin Ekonomi Teorisi'ni desteklemektedir. (ii) Yine bireylerin, işleri sürekli erteleme ve savsaklama özellikleri de ta- 
Tablo 1: Tasarruf Etmeyi Sağlayan Ampirik Kurallar

\begin{tabular}{|c|c|c|c|c|}
\hline Ampirik Kurallar & Örnek Eylem & Örnek Dürtme & $\begin{array}{l}\text { Dürtmenin } \\
\text { Kaynağ }\end{array}$ & $\begin{array}{l}\text { Dürtmenin İyi Çalışmasını } \\
\text { Sağlayan Mekanizma }\end{array}$ \\
\hline $\begin{array}{ll}\text { 1. Finansal } & \text { duru- } \\
\text { munuzu } & \text { düzenli } \\
\text { olarak } & \text { kontrol } \\
\text { edin. } & \end{array}$ & $\begin{array}{l}\text { Banka hesap- } \\
\text { larınızı ve kredi } \\
\text { kartı ekstrenizi } \\
\text { kontrol edin. }\end{array}$ & $\begin{array}{l}\text { Bireylerin } \\
\text { çekecek öğeleri vurgu- } \\
\text { layarak özel harcama } \\
\text { analizini kısa mesaj ile } \\
\text { gönderin. }\end{array}$ & $\begin{array}{l}\text { Banka hesabı } \\
\text { veya kredi } \\
\text { kartı için fi- } \\
\text { nansal hizmet } \\
\text { sağlayıcısı }\end{array}$ & $\begin{array}{l}\text { Bireyin harcamalarının } \\
\text { birleştirilmiş analizini } \\
\text { içeren kontrol paneli }\end{array}$ \\
\hline $\begin{array}{l}\text { 2. Borçlarınız sizi } \\
\text { yönetmesin, siz on- } \\
\text { ları yönetin. }\end{array}$ & $\begin{array}{l}\text { Borçlu } \\
\text { olduğunuz } \\
\text { paranın gerçek } \\
\text { maliyetini her } \\
\text { zaman bilin. }\end{array}$ & $\begin{array}{l}\text { Kredi kartı ekstrele- } \\
\text { rinin düzenli olarak } \\
\text { hatırlatmanın yanı sıra } \\
\text { kredinin maliyetini } \\
\text { açıkça gösterin. }\end{array}$ & $\begin{array}{l}\text { Kredi kartı } \\
\text { sağlayıcısı }\end{array}$ & $\begin{array}{l}\text { Daha ayrıntılı maliyet su- } \\
\text { numu ve açıklama stan- } \\
\text { dartları }\end{array}$ \\
\hline $\begin{array}{l}\text { 3. Az bile olsa ya- } \\
\text { pabildiğiniz sürece } \\
\text { tasarruf edin. }\end{array}$ & $\begin{array}{l}\text { Harcanabilir } \\
\text { gelirinizin/- } \\
\text { banka baki- } \\
\text { yenizin küçük } \\
\text { bir miktarnı } \\
\text { düzenli olarak } \\
\text { tasarruf edin. }\end{array}$ & $\begin{array}{l}\text { Bireylerin önceden be- } \\
\text { lirlenmiş küçük tasar- } \\
\text { ruflarının bir kısmını } \\
\text { 'yağmurlu gün fonu' } \\
\text { gibi anında erişim ta- } \\
\text { sarruf hesabına akta- } \\
\text { ran bir ürüne kaydedin. }\end{array}$ & $\begin{array}{l}\text { Banka hesabı } \\
\text { veya tasarruf } \\
\text { uygulaması } \\
\text { sağlayıcısı }\end{array}$ & $\begin{array}{l}\text { Otomatik tasarruf me- } \\
\text { kanizması ve gerekirse } \\
\text { hesaptan fazla para } \\
\text { çekimini önleyebilmek için } \\
\text { tasarruf hesabindan para } \\
\text { transferini kolaylaştıran } \\
\text { 'süpürme' hizmeti }\end{array}$ \\
\hline $\begin{array}{l}\text { 4. Gelecekteki ge- } \\
\text { liriniz olan emek- } \\
\text { lilik tasarrufunuzu } \\
\text { artırm. }\end{array}$ & $\begin{array}{l}\text { Yarın daha } \\
\text { fazla tasar- } \\
\text { ruf edin: } \\
\text { Gelecekteki ge- } \\
\text { lirinizi emekli } \\
\text { maaşınıza } \\
\text { yatırın. }\end{array}$ & $\begin{array}{l}\text { Çalışanlardan, gele- } \\
\text { cekteki kazançlarının } \\
\text { bir yüzdesini emekli } \\
\text { aylıklarına koymaların } \\
\text { isteyin. }\end{array}$ & İşveren & Yeni bir sistem kurulumu \\
\hline $\begin{array}{l}\text { Başkaları paralar } \\
\text { melinde bu kural } \\
\text { lllanın. }\end{array}$ & Indan en iyi şek & lde yararlanmak için & 0. & rik ku \\
\hline
\end{tabular}

sarruf etmelerini zorlaştırmaktadır. İyi bir dürtme uygulaması her şeyden önce bireylerin uzun vadeli faydaları göz önünde bulundurmalarını sağlamalı, tasarruf etmeyi kolaylaştıran esnek bir plan sunmalıdır. (iii) Öyle ki, iyi bir dürtmenin düşük gelirli bireylerin dahi tasarruf edebilmelerine olanak tanıması söz konusu olabilmektedir. Bu nedenle tasarruf etmeleri istenen bireylerin, en azından kısa dönemde ihtiyaç duymayacakları, bir köşede unutabilecekleri küçük meblağlı birikimler yapmalarını sağlamak yine etkili bir seçenek olabilmektedir. (iv) Ayrıca, bireylerin harcama günlükleri tutmaları önemli bir ayrıntı niteliği taşımakta ve sürekli harcama akışını gören bireylerin içsel bir dürtü ile harcamalarını kısıp tasarrufa yönelebileceği düşünülmektedir. (v) Bireyler için önce tasarruf edip daha sonra artan gelirlerine göre tüketimlerini ayarlamalarının da bireylerde irade eksikliğinin önüne geçerek tasarruf miktarının artmasını sağlayacak potansiyele sahip diğer bir strateji niteliğindedir. (vi) Bunlarla birlikte, bireylerin ne için tasarruf ettiklerine dair spesifik bir hedef koymaları onları teşvik edebilmektedir. (vii) Dürtme uygulamasının bireyleri yormaması ve kendinden uzaklaştırmaması adına erişilebilirliği de önem arz etmektedir. Bu nedenle artık neredeyse her bireyde bulunan cep telefonları aracıllğıyla mobil bankacılık ve finans uygulamalarının işlevselliklerinin artırılarak kullanımlarının sağlanması, cep telefonlarını önemli birer dürtme aracı olmalarını sağlayacaktır. Bunun yanında sosyal medya, reklamlar ve kamu spotları da önemli birer araç niteliği taşımaktadırlar. (viii) Bir işveren veya kamu otoritesi olarak ise bütün bunların yanında ayrıca dürtme niteliğinde nakdi tasarruf teşvikleri uygulamak yerinde bir seçenek olacaktır. 


\section{Sonuç Yerine}

Dürtme uygulamaları hem bir kamu politikası aracı hem de kamusal müdahale aracı olarak bireysel tasarruflarm artırılmasında önemli rol oynamaktadır. Son yıllarda sayıları giderek artan bu uygulamalara ilişkin ampirik bulgular, finansal okuryazarlık düzeyinin ve finans eğitiminin tek başına yeterli olmadığını, bireylerin irrasyonelliklerini doğrudan dikkate alan dürtmelerin ise tasarruf artı̧̧ı sağlamada başarılı araçlar olabileceklerini ortaya koymaktadır. Ancak söz konusu uygulamaların başarılı olmasının ardında bazı önkoşullar yatmaktadır. Bunların en başında dürtmenin yalnızca iyiye ve doğruya yönlendirerek zorunluluk içermemesini ifade eden dürtme etiği gelmektedir. Öyle ki, dürtmenin uygulayıcısı kamu otoritesiyse, özgürlükçü devlet (libertarian paternalism) yaklaşımı içerisinde olması gerekmektedir. Yine dürtmeyi, davranışsal iktisadın ortaya koyduğu bilişsel yanlılıklar kapsaminda ele almak dürtmenin etkisini artırmaktadır. Burada bireyleri tasarruf etmekten alıkoyan nedenlerin iyice bilinmesi ve dürtme tasarımının buna yönelik olarak yapılması söz konusudur. Bütün bu önkoşulları yerine getiren bir dürtme uygulamasının başarılı olmasının önünde neredeyse hiçbir engel bulunmamaktadır. Nihayetinde dürtme, bireylerin refah düzeylerinde artış sağlamak ve tasarruf yetersizliği sorununun önüne geçmek adına önemli işler yapmakta, bu tür uygulamaların geliştirilmesinin hem bireysel tasarruflarm hem de toplam tasarrufların artmasına ciddi katkılar sağlayacağı düşünülmektedir.

\section{Kaynakça}

Angeletos, G. M., Laibson, D., Repetto, A., Tobacman, J., ve Weinberg, S. (2001). The hyperbolic consumption model: Calibration, simulation, and empirical evaluation. Journal of Economic perspectives, 15, 47-68. doi:10.1257/jep.15.3.47

Ashraf, N., Karlan, D., ve Yin, W. (2006). Tying Odysseus to the mast: Evidence from a commitment savings product in the Philippines. The Quarterly Journal of Economics, 121, 635-672. http: //ssrn. com/abstract $=770387$.

Beverly, S. (1997). How can the poor save? Theory and evidence on saving in low-income household (Working Papers). Washington: Center for Social Development. doi:10.7936/K7251HP4

Bucher-Koenen, T., ve Lusardi, A. (2011). Financial literacy and retirement planning: How wellprepared are German households? (Web Article). VoxEU CEPR. https://voxeu.org/article/ financial-illiteracy-new-evidence-germany.

Can, B., ve Erdem, O. (2013). Present-bias in different income groups (Working Paper Series No. 3). Research Department of Borsa İstanbul. doi:10.26481/umagsb.2013008

Clark, R. L., Hammond, R. G., Morrill, M. S., ve Khalaf, C. (2017). Nudging retirement savings: A field experiment on supplemental plans (NBER Working Paper Series No. 23679). National Bureau of Economic Research. doi:10.3386/w23679

Dawnay, E., ve Shah, H. (2005). Behavioural economics: implications seven principles for policymakers. London: New Economics Foundation.

Emeklilik Gözetim Merkezi. (2020). Bazı bilgiler (Web Sayfası). Emeklilik Gözetim Merkezi. https://www. egm.org.tr/.

Financial Advice Working Group. (2020). Rules of thumb and nudges: improving the financial well-being of UK consumers (Report). The Treasury and FCA. https://www.fca.org.uk/publication/ research/fawg-rules-of-thumb-nudges .pdf.

Friedman, M. (1957). A Theory of the Consumption Function. Princeton: Princeton University.

Katona, G. (1975). Psychological economics. New York: Elsevier.

Lunt, P., ve Livingstone, S. (1991). Psychological, social and economic determinants of saving: Comparing recurrent and total savings. Journal of Economic Psychology, 621-641. doi:10.1016/0167-4870(91)90003-C

Lusardi, A., ve Mitchell, O. S. (2007). Baby boomer retirement security: The roles of planning, financial literacy, and housing wealth. Journal of Monetary Economics, 54, 205-224. doi:10.1016/j.jmoneco.2006.12.001

Messacar, D. R. J. (2016). Three essays on the behavioural economics of saving for retirement (Doctoral dissertation). Toronto: University of Toronto. https://tspace.library.utoronto.ca/ bitstream/1807/73045/3/Messacar_Derek_R 201606_PhD_thesis.pdf.

Modigliani, F., ve Brumberg, R. (1954). Utility Analysis and the Consumption Function: An Interpretation of Cross-Sectional Data. In F. Modigliani (Ed.), The collected papers of franco modigliani. Cambridge: The MIT Press.

Niwanthika, T. T. (2016). Determinants of Personal Savings: A Review of Literature. Journal of Economics, 32-43. http://repository.kln.ac.lk/ handle/123456789/16733.

Pektaş Erdem, B. (2017). Türkiye'de hanehalkı tasarruflarını etkileyen faktörler (Uzmanlık Tezi). Ankara: Kalkınma Bakanlığı Ekonomik Modeller 
ve Stratejik Araştırmalar Genel Müdürlüğü. http://www.sbb.gov.tr/wp-content/uploads/ 2018/11/Bet\%C3\%BC1PEKTA\%C5\%9EErdem.pdf.

Poterba, J. M. (2002). Tax Policy and Economy (Vol. 16). MIT and NBER.

Rocher, S., ve Stierle, M. (2015). Household saving rates in the eu: Why do they differ so much? (European Economy Discussion Paper No. 005). Luxembourg: Publication Office of the European Union. doi:10.2765/652169

Rodríguez, C., ve Saavedra, J. (2016). Household saving rates in the eu: Why do they differ so much? (CSD Working Paper No. 1619). Washington: Center for Social Development. doi:10.7936/K7QV3M1D

Shefrin, H. M., ve Thaler, R. (1977). An economic theory of self-control. The Journal of Political Economy, 98, 392-406. doi:10.1086/260971

Thaler, R., ve Sunstein, C. (2008). Nudge: Improving decisions about health, wealth and happiness. London: Yale University Press.

Thaler, R. H., ve Benartzi, S. (2004). An economic theory of self-control. Journal of Political Economy, 112, 164-187. http://www.jstor.org/ stable/1833317.

Zengin, S., ve Yüksel, M. T., S. abd Kartal. (2018). Türkiye'deki Düşük Hanehalkı Tasarrufuna Neden Olan Faktörlerin Belirlenmesine Yönelik Bir Araştırma. Journal of Yaşar University, 13, 86100. https://dergipark.org.tr/tr/download/ article-file/427380. 


\title{
Can the Nudge Affect Individual Savings? ${ }^{1}$
}

\author{
Meltem ERdoĞAN (10 ${ }^{2} \quad$ VEYSEl KARAGÖL (1) ${ }^{3}$ \\ Received:11.09.2020; Revised:29.09.2020; Accepted:07.12.2020
}

\begin{abstract}
The policies created by targeting individuals whose decisions are considered to have unlimited rationality are insufficient to solve the problems that have arisen today and in the past. However, being able to influence behavior is very important for public policy, also understanding the impact of people's behavior on the needs of the government and policy choices have recently been made aware of these effects. Individuals exhibiting irrational behavior cause behavioral economics to go a little further every day. The nudging, one of the applications of behavioral economics, aims to prevent irrational behaviors in simple and cost-effective ways and thus to guide individuals to good and right. So much so that the nudge is rapidly becoming an alternative public policy tool in many areas. With nudging, designing and implementing evidence-based, tested policies rather than traditional policy-making processes increases the chances of success of policies. From this point of view, it is only one of these areas to increase individual savings by guiding (nudging) the financial decisions of individuals. Is it really possible to increase individual savings by nudging? The aim of this study is to provide suggestions on whether the individual savings can be increased by nudging in view of how the nudging mechanism works and considering the empirical findings of nudging financial decisions.
\end{abstract}

JEL codes: D90, G51, J18

Keywords: Behavioral Economics, Nudge, Public Policy, Individual Savings

\section{Extended Summary}

Individual savings are defined by Poterba (2002) from two different perspectives. The first is to subtract individual expenditures from individual disposable income in a given time period. In the second definition, the first definition adds any capital loss or gain gained by individuals over existing assets in the same period, and thus individual savings are

\footnotetext{
$1 \mathrm{Bu}$ çalışma, II. International Conference on Economics - EconTR adlı kongrede sözlü bildiri olarak sunulmuştur.

2 İktisadi ve İdari Bilimler Fakültesi, Anadolu Üniversitesi, Eskişehir, Türkiye. (e-mail: melteme@anadolu.edu.tr)

3 İktisadi ve İdari Bilimler Fakültesi, Anadolu Üniversitesi, Eskişehir, Türkiye. (e-mail: vkaragol@anadolu.edu.tr)
}

defined as changes in net wealth in a certain period of time. Katona (1975) put forward a more micro-based definition of savings, saying that the average individual saves money by keeping their money in bank accounts or other assets in order to protect themselves from future uncertainty or to purchase goods and services in the future (Katona, 1975; Lunt ve Livingstone, 1991). Individual savings also have different dynamics apart from income and wealth. Besides demographic factors such as education, status, race, age and environmental factors, many factors such as uncertainty, interest rate, fiscal policy and access to financial markets affect individual savings decisions (Rocher ve Stierle, 2015). The importance of savings emerges in macro 
sense in connection with ensuring sustainable economic growth and development, and these are the main goals of developing countries. Countries develop many policy strategies to achieve these goals. Achieving these goals depends largely on the country's savings (Niwanthika, 2016). In order to achieve these savings with the determined targets, the importance of both public savings and the savings of each individual comes to the fore. However, this situation is not as easy as it might seem and countries may face the problem of insufficient savings. Especially for certain behavioral and psychological reasons, individuals avoid long-term savings and this situation leads to a decrease in individual wellbeing. Can ve Erdem (2013) and Zengin ve Yüksel (2018) indicated that to influence the decisions of individuals' savings and improve individual welfare in Turkey, policy interventions are needed.

Individuals' cognitive constraints often cause them to make unreasonable decisions and significantly affect their savings decisions. Therefore, especially in recent years, many different nudging practices have emerged aimed at encouraging and increasing individual savings. The nudging, one of the applications of behavioral economics, aims to prevent irrational behaviors in simple and cost-effective ways and thus to guide individuals to good and right. So much so that the nudge is rapidly becoming an alternative public policy tool in many areas. With nudging, designing and implementing evidence-based, tested policies rather than traditional policy-making processes increases the chances of success of policies. The main objectives of these practices are to raise awareness of individuals on financial planning and the use of money, and primarily to provide them with a comfortable retirement period. These practices are also seen as a necessary step for states to prevent potential social security system problems. The fact that individuals do not participate in any retirement plans, which is one of the ways of saving, is mostly due to their negligence and delay, not because they do not want to save. The sample group of nudge practices consists of exactly these individuals.

The aim of this study is to provide suggestions on whether the individual savings can be increased by nudging in view of how the nudging mechanism works and considering the empirical findings of nudging financial decisions. In individual savings decisions, earning a good income or having a basic knowledge of economics and finance is not always sufficient, so individuals need to be guided in the savings decision process. In this context, we try to explain the different successful ways of nudging people to save more first. Thus, changing the default option rule has been explained as the first way to include individuals in any savings plan. In other words, in the absence of any active election, the situation exposed should not be changed to not to participate in this system, but rather to participate. Thus, the individual is automatically included in this plan and is expected to fill out a document in case he wants to leave this plan. The second way is to ask individuals if they want to participate in the savings plan when starting work, with as simplified registration forms as possible. Because as the number of options increases, confusion occurs in individuals and some people may give up choosing. Turkey has applied this type of nudging in 2017 with a success. Another way is allowing individuals to set their own contribution rates. Here, the government or employer can provide a contribution for a minimum amount of savings an individual makes. In this study, Save More Tomorrow-(SMarT) Program of R. H. Thaler ve Benartzi (2004) which tries to help employees who want to save more but do not have the will to act according to this desire is also included. In this program, as the salaries of individuals increase, their savings rate increases at the same rate. In the following years, many retirement plan managers have adopted this program and it has been found that it gives more effective results when used with an automatic participation system (R. H. Tha- 
ler ve Benartzi, 2004; R. Thaler ve Sunstein, 2008). The promotion of increasing individual savings does not only involve retirement planning, it actually concerns people of all ages who earn a certain income. Rodríguez ve Saavedra (2016) examined the effects of financial status information messages transmitted via mobile phones on financial decisions.

Suggestions for effective nudge practices to increase savings are also included in the study. Successful results have been obtained in increasing individual savings with the nudge applications that have taken place in many areas in recent years. However, in order to obtain these results, it is absolutely necessary to consider two facts. The first of these is to clearly inform the individuals who want to be directed to save and why they should do this. Although, an educational structure that will inform all individuals on this subject is an indisputable fact, an important finding obtained by empirical studies that raising awareness through education and information alone shows that it is not enough. Practices that consider the deviation of individuals from this rationality, known as cognitive biases, is the second important issue that will enable successful results in increasing savings. Knowing the cognitive biases that prevent individuals from saving will lead to the preparation of practices that specifically address these biases and will bring success with it. Taken together, these two issues remain to design effective nudging practices that are good and true, cost-effective, and no obligation. Accessibility of the application is also important in order not to tire individuals and not to distance themselves. For this reason, increasing the functionality of mobile banking and finance applications through mobile phones, which are now available to almost every individual, will enable them to become an important means of nudging. In addition, social media, advertisements and public service ads are also important tools. As a public authority, besides all these, it would be an appropriate option to implement savings incentives in the nature of nudging. Again, considering the nudging within the scope of cognitive biases revealed by behavioral economics increases the effect of nudging.

Here, it is a matter of knowing the reasons that prevents individuals from saving and making the nudging design accordingly. There is hardly any obstacle to the success of a nudge application that fulfills all these prerequisites. Ultimately, nudging does an important job in order to increase the welfare of individuals and to prevent the problem of insufficient savings, and it is thought that the development of such practices will significantly contribute to both individual savings and total savings. 